\title{
The Relationship between Ethical Leadership Styles and Employees Effective Work Practices
}

\author{
Anrusha Bhana ${ }^{1} \&$ Mohamed Saheed Bayat ${ }^{2}$ \\ ${ }^{1}$ Department of Financial Accounting, Faculty of Accounting and Informatics, Durban University of Technology, \\ KwaZulu-Natal, South Africa \\ ${ }^{2}$ Adjunct Professor, Department of Public Administration, University of Fort-Hare Alice ,Eastern Cape South \\ Africa and University of Lusaka, Zambia
}

Correspondence: Dr Anrusha Bhana, HOD (Acting), Department of Financial Accounting, Faculty of Accounting and Informatics, Durban University of Technology, KwaZulu-Natal, South Africa, 4001.

Received: March 29, 2020

doi:10.5430/ijhe.v9n4p128
Accepted: May 17, 2020

Online Published: May 19, 2020

URL: https://doi.org/10.5430/ijhe.v9n4p128

\begin{abstract}
South African Higher Education Institutions are diverse, highly debated by academia as well as the portfolio committee on higher education and structured with a strong focus on the customer being students, with a negligible concern for the academic and professional employees. The revolutionary changes at Higher Education Institution have gestured the importance of both leadership and employees to support the transformational strategy at these institutions. Higher Education transformation has a lot to do with leadership - not the leadership of the Vice-chancellor, but the leadership of a collective of people, executive management leadership, line management leadership, academics and administration, and other stakeholders (MacGregor, 2015:28; 2012). The aim of the study was to examine the relationship between the ethical leadership style of line management leadership, and academic and administrative at a South African Higher Education Institution in KwaZulu-Natal. Data analysis utilized a quantitative method with an academic sample size of 165 (52.9\%) and administrative sample size of 147 (47.1\%). The study used descriptive and linear regression analysis to examine the two variables. The descriptive findings revealed that ethical leadership style was not present at the line management leadership level. The inferential analysis findings exhibited a significant strong linear relationship of $74.7 \%$ between line management leadership and employee items. Data analysis revealed that line management leadership style had an impact on employees' performance and behavior at the institution. Thus, it is imperative to have a fully engaged workforce in order for an institution to achieve greater levels of innovation, intrapreneurship, design thinking and financial management.
\end{abstract}

Keywords: ethics, ethical leadership, higher educational leadership, academic employees, administrative employees, line management leadership, higher education institutions

\section{Introduction}

Over the years, there have been various sectors of South African leadership that subjugated the media for positive and negative reasons. Various ethical problems are now being reported in government, medicine, banking, business and labour sectors (Kretzschmar and Bentley, 2013:1). South African Higher Education Institutions (SAHEIs) have been known as diverse, highly debated and structured with a minimal emphasis on the importance of leadership and employee relationship. In this regard, Higher Education Institutions (HEIs) require leadership with strong personal, relational and knowledgeable proficiencies (Ngcamu and Teferra 2015a), as HEIs are different and require leadership to be a more collective phenomenon in comparison to other profit-centred organisations (Van Niekerk, 2005:55, 71). Customarily, most SAHEIs view effective leadership as an imperative not only at the top levels, but also at lower levels as well. Some researchers claimed that educators are leaders or that leadership styles are similar to teaching styles, and that educator's behaviour is identical to leadership behaviour (Al-Omari, 2005:33; cited Swanson, 1974, Gibb, 1955). However, Kulati and Moja (2001) asserted that there have been no undertakings or tasks to evaluate the most appropriate leadership style or styles that positively influence South African Higher Education Institutions. For anyone to be revered as an effective leader they should have followers or employees and not work in isolation which has been supported by Van Niekerk (2005:38) that a leader can be defined as someone who has followers. The definition of a leader is an individual who should try to inspire one or more followers and guide these followers to accomplish a specific objective (Sethuraman and Jayshree, 2014). Employees or staff are-customarily known as 
'followers' or organisational followers of the leader at different levels of an institution. The working force of South African Higher Education (SAHE) comprises of two cohort of employees being academic and administrative support staff. Academic and administrative employees are imperative for sustainability, economic development and institutional support-and play a vital part in the economic growth and future of South Africa (Van Niekerk, De Klerk, and Pires-Putter, 2017). Wiza and Hlanganipai's (2014:141) study claimed a link between leadership styles and employee commitment theories amongst university academics at some South African institutions. Previous studies suggested (Fernandez, 2008; Lin and Tseng, 2013; Shaw and Newton, 2014; Yang, 2014) that the correct leadership style might improve employee work satisfaction and well-being. Hansen, Byrne and Kiersch (2014: 967) maintained that this topic is still new, researchers would need to propose clear reasons for how leadership is linked to employees work practices.

The revolutionary changes at several Higher Education institutional levels has gestured the importance of effective and ethical leadership relative to employees. SAHE and other universities worldwide are facing major transformational challenges that need remarkable leadership (Van Ameijde, Nelson, Billsberry and Van Meurs, 2009). Several lower level leaderships such as line management leadership (supervisory) and middle management, and executive management leadership have influenced faculties and departments in an unethical manner with an overt disregard for stakeholders. According to Ngcamu and Teferra (2015b:208) the shortcoming in South African Higher Education (SAHE) is the ineffectual and inefficient leadership which seems to stifle the transformation agenda. 'Effective' leadership rather than 'ethical' leadership seems to be the popular term used at different Higher Education Institutions within South Africa, yet the current demand for efficient and ethical leadership seems to be greater than the supply of it. The recent emergence of ethical leadership as an acknowledged leadership theory, especially amid persistent corporate scandals, mismanagement and societal disputes, confirm the relevance and importance of it (Grobler and Horne, 2017:166). Previous researchers supported that ethical leadership has many positive outcomes including better employee performance, trust in leaders, organizational commitment, added effort, job fulfilment to emotional commitment (Cheng, Chang, Kuo, and Cheung, 2014: 817; cited Kuo, 2013; Avey et al., 2011; Walumbwa et al., 2011). Higher Education (HE) leadership constituents require emphasis on the external environment and internal operation of the institution (Taylor and Machado, 2006:143).

\section{Literature Review}

\subsection{South African Higher Education Institutions Leadership}

Gumede (2014:68) stated that HE is well-defined as post-secondary education, progressive third stage learning at the diploma and degree levels in a traditional HE environment. However, SAHEIs are gradually becoming challenging places to rule, manage and lead (Mabelebele, 2013:2). Catastrophes including financial mismanagement and lack of accountability, vulnerability to nepotism, undue influence, conflict of interest, embezzlement of funds, have a direct impact on priorities such as student centeredness and providing quality education (Grobler and Horne, 2017:154-155). In addition, it is noteworthy to express that Higher Education leaders are not equivalent to the leaders of other categories of creative organizations (Council on Higher Education, 2016:49).

There has been significant interest in the subject of HE leadership as research has increased over the last decades (Alonderiene and Majauskaite, 2016:140). The Council for Higher Education (2016) asserted that HEIs academic leadership had become progressively challenging in the fast-changing global realities, and was even more complex in South Africa. Leadership is a key to the efficient administration of educational transformation and revolution (Van Niekerk, 2005), however, SAHEIs are led by people lacking leadership proficiencies, thus are directly impeding transformation initiatives and programs within institutions (Ngcamu and Teferra, 2015a:209). As stated by Awung (2014:22-23) a HE leader must motivate faculty, staff, students and citizens of the nearby community to support and understand the institutions goals. According to Quintal (2012:2) ethical leadership would connect with the notion of the African renaissance. Thus, the responsibility of HEIs is to sustain ethical values and to nurture an ethical culture has never been more important (Grobler and Horne, 2017:154). The Council for Higher education (2016:78) proposed that an effective Higher Education leader should have fundamental distinct leadership behaviours, and be willing to engage and convince employees to follow and enable mutual respect.

\subsection{Leadership Employee Relationship}

Leaders are the most important role models as the leader has a major socializing influence on lower-level employees and ethical conduct from an organizational context (Van Zyl, 2014:6). When leaders are steadfast in their duties and responsibilities, employees receive clear indications about what is imperative in the organization (Sims and Brinkmann, 2002:331). Graen and Uhl-Bien's theory of leadership suggested that leadership should be understood in three different domains: follower, leader, and relationship aspects (Graen and Uhl-Bien, 1995). The philosophies of 
management and managerial conduct have a major influence on the ethical behaviour of employees (Van Zyl, 1999:19). There is a positive relationship outcome when leaders suggest openness in relation to employee duties and responsibilities (Mukherjee and Malhotra, 2006). An employees' behaviour is known based on the trust relationship between the leader and employee (Mardanov, Heischmidt and Henson, 2008:159-175). To ensure employee job satisfaction an intensive resolution should be directed towards leadership and management styles, individuals in executive management positions such as Deans and Directors, and line management leadership such as Heads of Departments (Schulze, 2006:322). Schaufeli and Bakker (2001) stated that employees' dedications arose from a sense of meaning from their job, feeling passionate and satisfied about their job, and feeling encouraged and positively challenged by their work. Brown, Treviño and Harrison (2005) claimed that followers deem ethical leadership style to be effective.

\subsection{Ethics and Ethical Leadership Definition and Style}

Helmrich (2016) terms 'leadership' as having the competence to lead people. Another definition of leadership would be the means of influencing, encouraging, supporting, helping and inspiring employees to pursue organisational goals through the means constructed by all stakeholders (Shokane, Stanz, Slabbert, 2004:1). Ethics can be defined as the form of knowledge that deals with the study of universal philosophies that determine right from wrong (Oates, 2013:38). The Young African Leaders initiative defined ethics as being a system of doctrines that influences action (Van Zyl, Dalgish, et.al., 2016:171). Every religious conviction contains ethics; the Sermon on the Mount and the Ten commandments of Lord Jesus comprise ethical knowledge for the improvement of mankind, the Noble Eightfold path of Lord Buddha is the crux of ethics and the Gita of Hinduism is ethics in a deepened form (Sivananda, 2007:2). Ethics and ethical conduct are moral and social standards that warrant doing more than just conforming with laws and regulations, but to do what is right with emphasis on goodness in behaviour (Sindane, 2011:766). Bayat and Naidoo (2017:42) claimed that ethics should be at the core of all human being relationships and thus at the heart of the relationship between leaders and followers.

By merging the two definitions of ethics and leadership, one can quickly develop simple definition for ethical leadership (Oates, 2013:38). Ethical leadership has its source in ethical conduct or ethics (Van Zyl, 2014:8). Ethical leadership style can be defined exhibiting appropriate conduct, and modelling proper behaviours by way of suitable communication, support and decision-making (Brown, Trevino and Harrison, 2005:120). Moreover, Zuma (2000:6) suggested that ethical leadership style could be defined as leading in a manner that respects the rights and dignity of others. It is the connection between leaders and followers that places ethics to be fundamental to leadership (Van Zyl et al., 2016:172).

\subsection{Importance of Ethical Leadership}

The Council for Higher education (2016) recently reported that the pressures and tensions of leadership takes a toll on academic and administrative support staff in diverse ways. Ethical leaders are known to establish an atmosphere that positively impacts employee goals and behaviour (Mayer, Kuenzi, Greenbaum, Bardes, and Salvador, 2009:1-13). Furthermore, ethical leadership ensures that employees have a better work outlook, more committed and immersed in the job (Brown, Treviño, and Harrison 2005).

Ethical leadership styles may positively impacton employee well-being, however research on this subject is lacking (Kalshoven and Boon, 2012:61). According to Trevino, Brown, and Hartman (2000:128-142; 2003:5-37) leaders become attractive and credible ethical role models when observed by employees as both a moral being and a moral leader. Furthermore, Heres and Lasthuizen (2013:96) maintained that ethical leadership also influences employees' relationship with the leader, team and general organization. Ethical leadership fosters trust not only in the leader, but amongst colleagues (Den Hartog and De Hoogh, 2008). It is important that all managers accept responsibility and accountability for supervising or policing the ethical code of conduct (Van Zyl and Lazenby, 1999:21). According to Kalshoven and Boon (2012:60) ethical leaders offer job resources such as role explanation or open support, therefore ethical leadership communicates positively to employee well-being. Ethical leadership makes employees feel like there is positive influence over an occupation and an individual's job becomes more meaningful (Heres and Lasthuizen, 2013:95). Ethical leadership impacts work relationships as well as other organizational outcomes, and positively influences work engagement (Engelbrecht, Heine and Mahembe, 2014:2).

\subsection{Ethical Leadership Impact on Employee Relationship}

The crucial part of ethical leadership is the moral management qualities that separate it from other leadership styles, thus making it effective in cultivating ethical decision-making and ethical behavior in followers (Brown and Treviño 2006). Jewe (2008) stated that the Ethical Resource Centre claimed that managers who modelled ethical behaviour 
had a major decrease of misconduct then leaders and managers who did not model ethical behaviour. As Technology (2016:61-62) asserted that the Institutions Code of Ethics as endorsed by Council is a declaration of the ethical doctrines, values and behaviours expected of the employees and individuals connected to the Higher Education Institution. The original research was customarily denoted as a moral person element of ethical leadership (Treviño, Hartman, and Brown, 2000) that is connected to a leader's moral standards and behaviours along with respective decision-making and conduct (Heres and Lasthuizen, 2013:82). Furthermore, Ofori (2009:533-547) stated that ethical leadership may play a facilitating part as a link between organizational culture and employee outcomes. Brown, Trevino and Harrison (2005) claimed that ethical leadership was linked to better employee motivation, and more positive work performance. Employees who are observing leaders will be influenced by the ethical behaviour observed and the leader's skills, not a general view related to only human nature (Brown, Trevino and David, 2005: 121). Kalshoven and Den Hartog (2009:102) believed that ethical leadership style improved the trust amongst employees, and these leaders would then be regarded as effective leaders. Brown, Trevino and Harrison (2005:123) claimed that ethical leadership style would be noticeably associated with employees' readiness to report any issue to the leader. It is therefore important that all leaders accept responsibility and accountability for supervising or policing the ethical code of conduct (Van Zyl and Lazenby, 1999:21). Mendes and Stander (2011:3) stated that it was necessary to examine the role of a leader as the leader had a significant impact on the success of employee empowerment.

\section{Method}

The aim of this research was to examine the relationship between ethical leadership style of line management leadership and employees at a South African Higher Education Institution (SAHEI) in KwaZulu-Natal.

The research utilised the probability sampling method. In probability sampling method each section of the population has an acknowledged zero probability of being chosen (Creswell et al.,2016:192). The simple random sampling technique was utilised for the validated quantitative research instrument of the study. Simple random sampling offers each component in the target population an equivalent chance of being nominated (Briggs and Collman, 2007: 204). Ncgamu and Teferra (2015:211) claimed that the quantitative method used in an employee study included structured questionnaires to reach several employees thus ensuring feasible quantification of the results. The primary data comprised closed-ended questionnaires that respondents selected from the Likert 5-point scale for leadership and employee items. A Likert scale is a variation rating scale that is most commonly used when an organization plans to conduct research or commence with a program of change or development (Blumberg, Cooper, and Schindler, 2014: 418). The sample population used the SAHEI two regional campuses being Durban and Pietermaritzburg campus in KwaZulu-Natal. Due to each campus having different populations, the regional approach to sample selection needed to be utilised. The sample population was 420 which 312 questionnaires were returned representing a response rate of $74 \%$. The respondents consisted of academic staff sample size of $165(52.9 \%)$ and administrative staff sample size of $147(47.1 \%)$.

The nearer Cronbach's Alpha to 1 the higher would be internal reliability (Sekaran, 2016:307). The reliability of the scales utilized in the research instrument was measured by the coefficient of reliability using Cronbach Alpha $(\alpha)$. Thus, the reliability of the scales which described the ethical leadership style of line management leadership $(\alpha 0.981)$ as well as employee items ( $\alpha$ 0.954) survey were excellent.

\section{Analysis of Data}

\subsection{Descriptive Analysis}

The descriptive analysis commenced with the mean values and standard deviation utilizing Likert 5-point scale statements of strongly disagree to strongly agree. The findings revealed a weak mean value score and standard deviation regarding ethical leadership style of line management leadership items which was measured using the line management leadership (LML) 9 Likert 5-point scale (strongly disagree to strongly agree), mean value score and standard deviation. Hence, the mean value scores and standard deviation were reported in descending order, as follows:

"Strives to fulfill the goals and objectives of the university through the department" recorded the highest mean value $(\mathrm{M}=2.89, \mathrm{SD}=1.304)$; "Is passionate and dedicated" being the second mean value $(\mathrm{M}=2.77, \mathrm{SD}=1.358)$; "Supports staff personal and professional development" was the fifth mean value ( $\mathrm{M}=2.73, \mathrm{SD}=1.287)$; "Encourages two-way communication that promotes open, honest dialogue and understanding" being the sixth mean value $(\mathrm{M}=2.73, \mathrm{SD}=1.297)$; "Focuses on building staff respect, trust and equality" $(\mathrm{M}=2.57, \mathrm{SD}=1.238)$; "Allows employees to influence critical decision-making" $(\mathrm{M}=2.51, \mathrm{SD}=1.265)$; "Is transparent and ethical" $(\mathrm{M}=$ 
$2.46, \mathrm{SD}=1.298)$; "Is a good role model?" $(\mathrm{M}=2.46, \mathrm{SD}=1.267)$; and "has necessary skills to manage employee conflict, mistakes and complaints, conversely", was the lowest mean value $(2.40, \mathrm{SD}=1.254)$. Distinctively, the average mean value score $(\mathrm{M}=2.65, \mathrm{SD}=1.291)$ exhibited a weak strength mean value score of less than 3.00. Hence, a weak mean score value for all line management leadership items.

The findings demonstrated the frequency distribution using 9 Likert 5-point scale statements (strongly disagree to strongly agree), mean value scores and standard deviation ranging from highest mean $(\mathrm{M}=2.86, \mathrm{SD}=1.253)$ to lowest mean $(\mathrm{M}=2.33, \mathrm{SD}=1.136)$ for employee items. The mean value scores and standard deviation for respondents have been reported in descending order, as explained below:

"I have a good working relationship with LML" was the highest mean value $(\mathrm{M}=2.86, \mathrm{SD}=1.253)$; followed by "my LML supports employees career development" was the second mean value ( $\mathrm{M}=2.86, \mathrm{SD}=1.197)$; "LML is concerned about staff well-being" $(\mathrm{M}=2.67, \mathrm{SD}=1.205)$; "Able to discuss personal matters or report a problem to HOD" $(M=2.65, \mathrm{SD}=1.259)$; "Staff are comfortable to raise issues and ask questions to the HOD" $(\mathrm{M}=2.64, \mathrm{SD}$ $=1.290)$; "Employees are happy and part of a family in the department" $(\mathrm{M}=2.56, \mathrm{SD}=1.333)$; "LML inspires and encourages me to perform better" $(\mathrm{M}=2.54, \mathrm{SD}=1.288)$; "My HOD is my confidant and genuinely cares" $(\mathrm{M}=$ $2.45, \mathrm{SD}=1.183)$; and "I am involved in final decision-making" $(\mathrm{M}=2.33, \mathrm{SD}=1.136)$ had the lowest mean value score $(\mathrm{M}=2.33, \mathrm{SD}=1.136)$. Noticeably, the average mean value $(\mathrm{M}=2.62, \mathrm{SD}=1.238)$ for overall statements have also exhibited a weak mean value score of less than 3.00.

\subsection{Inferential Analysis}

Linear regression analysis assessed the coefficient of determination $\left(\mathrm{R}^{2}\right)$ to predict if one independent variable has a relationship with the dependent variable. Hence, the regression model (Table 4 and Table 5) was utilized to analysis if there was a predictive relationship between line management leadership (IV) and employee items (DV).

$\mathrm{H} 1_{\mathrm{o}}$ : There is no significant positive linear relationship between line management leadership and employees.

$\mathrm{H}_{1}$ : There is a significant positive linear relationship between line management leadership and employees.

The results revealed a predictive relationship between line management leadership (IV) and employee items (DV). The LML variable was utilized to predict the value of employee item. The $\mathrm{R}$ is 0.864 , thus (coefficient of determination) $\mathrm{R}^{2}=0.864 \times 0.864=0.747$. As a result, the model summary revealed that the percentage of $74.7 \%$ $\left(\mathrm{R}^{2}=0.747\right)$ variation in employee items that could be explained by line management leadership. In addition, there is a clear indication of a very strong positive correlation as the adjusted $\mathrm{R}^{2}$ is high (Adjusted $=0.746$ ). Thus, $74.6 \%$ of the variation in employee items can be explained by LML in the regression equation model. Therefore, LML accounts for $74.7 \%\left(R^{2}=.747\right)$ of the variance in employee items, $F(1,310)=916.282, p=0.000$. The statistical significant value of the F-value is less than 0.05 that showed a significant amount of variance in employee items.

The regression coefficient of regression equation was used to predict employee items. LML was found to be a significant predictor of employee items, $\beta=0.808, p=0.000$. In addition, the statistical significant value of $t$ (30.270), $\mathrm{p}=0.000$ demonstrated that for each LML item there is a positive correlation with employee items.

The regression equation $(\mathbf{Y}=\mathbf{a}+\mathbf{b} \mathbf{X})$ will be Employee items $=0.540+0.808 * \mathrm{LML}$

The regression equation shows $\mathbf{Y}$ is employee items (DV), $\mathbf{X}$ is the line management leadership (IV), $\mathbf{a}$ is the constant, and $\mathbf{b}$ is the beta coefficient. Since, the unstandardized beta coefficient is positive $(\beta=0.808)$, it implied that for every one-unit increase in LML value, the employee items variable increases by 0.808 units, therefore a statistical significant regression model. Moreover, LML has a strong significant influence on employee item scores. Thus, it can be concluded that there is sufficient evidence at the 5\% level of significance that there is a positive linear relationship between LML and employee items. Therefore, $\mathrm{H} 1_{1}$ was accepted.

\section{Results}

The descriptive results for ethical leadership style showed that line management leadership reflected strong disagreement across all nine statements. This finding is further supported by the descriptive findings that revealed a disagreement in employee items related to line management leadership. These results implied that there is a disagreement regarding LML respecting employees' different needs, abilities, and aspirations, supporting employee personal and professional development, and encourages self-management. Moreover, a low mean value $(\mathrm{M}=2.46$, $\mathrm{SD}=1.298$ ) for the two LML items being ethical and transparent with $54.5 \%$ disagreement, and good role model with 56\% disagreement has demonstrated the need for ethical leadership style at line management level. In addition, $58.9 \%$ of employees were not involved in decision making, followed by $53.5 \%$ of LML are not employees' confidant and genuinely cares for them. Moreover, the average weak mean score value of below $\mathrm{M}=3.00$ for line management 
leadership and employee items displayed a weak relationship between LML and employees. Thus, the results revealed that ethical leadership style was not present at line management leadership level.

The linear regression analysis showed a relationship between the one independent and dependent variable relative to ethical leadership style. The findings implied that there is a strong predictive relationship $(74.7 \%)$ that can be explained between line management leadership and employee items. The results indicated a significant positive linear correlation between LML and employee items with a significant value of $\mathrm{t}(30.270), \mathrm{p}=0.000$, thus, supporting the measurement into the relationship between ethical leadership style of LML and employee items.

\section{Discussion}

The descriptive findings showed a disagreement regarding evidence of ethical leadership style of line management leadership and employee items. The findings revealed the highest mean value $(\mathrm{M}=2.89, \mathrm{SD}=1.304)$ for $\mathrm{LML}$ was striving to fulfill the goals and objectives of the university through the department. This is further supported by Sims and Brinkmann (2002:331, when leaders are steadfast in duties and responsibilities, employees receive clear indications about what is imperative to the organization. All leaders at different levels of any institution and especially HEI should always ensure that departmental goals and objectives relative to the faculty and university are achieved. Fulfilling institutional goals and objectives should be a mandate for all ethical leaders, however if leadership focus is on personal agendas rather than institutional agendas it will sooner or later have a negative ripple effect on all stakeholders concerned. Moreover, the results showed a $46.8 \%$ disagreement that their line management leadership is passionate and dedicated, which was also the second highest mean value $(\mathrm{M}=2.77, \mathrm{SD}=1.358)$. Schaufeli and Bakker (2001) stated that employees' dedication arises from a sense of meaning from an individual's job, feeling passionate and satisfied about the job, feeling encouraged and positively challenged by the work. Thus, implied that LML are not satisfied, positive or happy in these positions which has also been observed by employees. Furthermore, the findings showed a 52.2\% disagreement that LML do not allow employees to influence critical decision-making, which was in correlation with 58.9\% disagreed that employees are involved in final decision-making. As stated by Van Schalkwyk, Willmers and Czerniewicz (2014:6) leadership lacking informed decision-making will potentially promote weak and divided institutions susceptible to immorality and/or the inappropriate allocation of resources. The original predominant research was customarily denoted as a moral person element of ethical leadership (Treviño, Hartman, and Brown, 2000) that is connected to a leader's moral standards and behaviours along with respective decision-making and conduct (Heres and Lasthuizen, 2013:82). In addition, the findings revealed that 51\% disagreed that LML focuses on building staff respect, trust and equality, followed by $48.1 \%$ disagreed employees are able to discuss personal matters or report a problem to their LML. These findings revealed that employees do not have a trust relationship with their LML to discuss important work or personal matters. This is consistent with Engelbrecht, Heine, and Mahembe (2014:3) assertion that ethical leadership style embraces diverse qualities that are evident in the trusting relationship between a leader and follower. Moreover, HEIs new responsibilities require sound management, effective leadership and strong governance structures for effectual and proficient management (Barac, Moloi and Marx, 2011:317).

A limitation of the study was that it utilised one Higher Education Institution in KwaZulu-Natal as the inclusion of other universities would have made the study too longitudinal in nature. Hence, the emphasis of the study was based on one SAHE institution. Thus, the study findings were delimited to employees of the one higher education institution in KwaZulu-Natal. The utilization of one institution allowed the researcher to access employees more easily due to the proximity of sample population. Nevertheless, most of the employees were eager, cooperative and agreed to contribute to the study. Thus, this study findings is sensitive to the sample size of one HEI and asserts cautiousness as it is not possible to generalize these findings to other Higher Education Institutions. Moreover, the study was based on a single higher education institution environment that supported the need for ethical leadership practices and employee engagement. These significant findings are limited to the biographical confines of the study sample population.

The aim of the study was achieved from the findings in relation to a relationship between LML and employee items. The hypothesis examined if line management leadership items was a significant positive predictor of employee items. The alternative hypothesis was accepted as line management leadership had a significant linear positive relationship with employees' items. This was supported by Van Zyl (2014:6) that leaders are the most important role models as these leaders have a major socializing influence on lower-level employees and ethical conduct from an organizational context. Hence, the regression equation model (Table 4$)$ results $\left(\mathrm{R}^{2}=0.747\right)$ indicated that the line management leadership style had an impact on employees at the institution. Thus, the percentage dimension of $74.7 \%$ affirmed a line management leadership and employee relationship. As concurred by Hirtle (2016:5) that pressure has 
been placed on the line management leadership to ensure that employees are working as the key reason for employees to work as opposed to leaving the employment.

\section{Conclusion}

The paper examined the relationship between line management leadership and employees at a SAHEI in KwaZulu-Natal via descriptive and inferential analysis which was achieved and supported by the findings that revealed a predictive relationship betweenthe ethical leadership style of line management leadership and employee items. The alternative hypothesis testing therefore was accepted and uniform with the results of a predictive relationship between the independent and dependent variable. The results indicated that different leadership styles be them ethical or unethical, influences the academic and administrative support employees' behaviours and performances. Thus, line management leadership need to understand that promoting ethical leadership at Higher Education Institutions will advocate moral values that will inherently support the goals and objectives of departments and overall institution. Global literature indicated that ethical leadership facilitates ethical role-modelling, better decision-making, communication and work trust in an institution. The descriptive findings revealed that ethical leadership style was not present at line management leadership level. A leader's reputation should be the cornerstone of a department, faculty or institutions long-term and overall success. Moreover, employees' well-being and behaviour is imperative to support and ensure sustainability at departmental and faculty levels of an institution. In contrast, if employees are discontent with line management leadership styles it will have an impact on all the other stakeholders at the institution. Thus, an enhanced ethical leadership climate will ensure that all stakeholders being employees, external collaborators, and students understand what is expected at the institution.

\section{References}

Al-Omari, A. A. (2005). Leadership styles \& style adaptability of deans \& department chairs at three public research universities. $\mathrm{Ph}$. D, Washington State University. Available: https://research.libraries.wsu.edu/xmlui/bitstream/h\&le/2376/340/a_alomari_050305.pdf?sequence=1 (Accessed 21 September 2015).

Alonderiene, R. \& Majauskaite, M. (2016). Leadership style \& job satisfaction in higher education institutions. International Journal of Educational Management, 30(1), 140-164. https://doi.org/10.1108/IJEM-08-2014-0106

Avey, J.B., Palanski, M.E. \& Walumbwa, F.O. (2011). When leadership goes unnoticed: the moderating role of follower self-esteem on the relationship between ethical leadership \& follower behavior. Journal of Business Ethics, 98(4), 573-582. https://doi.org/10.1007/s10551-010-0610-2

Awung, M. (2015). Factors influencing the career progression of women in higher education: The case of the Durban University of Technology. Masters of Technology, Durban University of Technology.

Barac, K., Moloi, T. \& Marx, B. (2011). Corporate governance practices at South African higher education institutions: an annual report disclosure analysis. Journal of Economic \& Financial Sciences, 4(2), 317-332. https://doi.org/10.4102/jef.v4i2.323

Naidoo L.D.,Bayat, M. S. \& Naidoo, B. B. (2017). Leadership Governance: An Ethical Consideration. E -Journal Developments in Administration, (2), 39-41.

Blumberg, B.F., Cooper, D.R. \& Schindler, P.S. (2014). Business research methods. 4th edn. Berkshire: McGraw-Hill education.

Briggs, A.R. \& Coleman, M. (2007). Research Methods in Educational Leadership \& Management. 2nd ed. Sage Publications.

Brown, M.E. \& Treviño, L.K. (2006). Ethical leadership: A review \& future directions. The Leadership Quarterly, 17(6), 595-616. https://doi.org/10.1016/j.leaqua.2006.10.004

Brown, M. E., Treviño, L. K. \& Harrison, D. A. (2005). Ethical leadership: A social learning perspective for construct development \& testing. Organizational Behavior \& Human Decision Processes, 97(2), 117-134. https://doi.org/10.1016/j.obhdp.2005.03.002

Cheng, J.W., Chang, S.C., Kuo, J.H. \& Cheung, Y.H. (2014). Ethical leadership, work engagement, \& voice behavior. Industrial Management \& Data Systems, $114(5), \quad 817-831$. https://doi.org/10.1108/IMDS-10-2013-0429

Council for Higher Education. (2014). Reflections of South African university leaders 1981 to 2014 South Africa: African Minds \& Council on Higher Education. Available: 
http://www.che.ac.za/sites/default/files/publications/Reflections\%20of\%20South\%20African\%20University\%2 0Leaders\%201981-2014.pdf

Creswell, J., Ebersohn, L., Eloff, I., Ferreira, R., Ivankova, N., Jansen, J., Nieuwenhuis, J., Pietersen, J., Plano Clark, V. \& Van der Westhuizen, C. (2016). First steps in research. 2nd ed. South Africa

Engelbrecht, A. S., Heine, G. \& Mahembe, B. (2014). The influence of ethical leadership on trust \& work engagement: An exploratory study. SA Journal of Industrial Psychology, 40(1) https://doi.org/10.4102/sajip.v40i1.1210

Fern\&ez, S. (2008). Examining the effects of leadership behavior on employee perceptions of performance \& job satisfaction. Public Performance \& Management Review, 32(2), 175-205. https://doi.org/10.2753/PMR1530-9576320201

Gibb, C. (1955). Classroom behavior of the college teacher. Educational \& Psychological Measurement, 15, 254-263. https://doi.org/10.1177/001316445501500305

Graen, G. B. \& Uhl-Bien, M. (1995). Relationship-based approach to leadership: Development of leader-member exchange (LMX) theory of leadership over 25 years: Applying a multi-level multi-domain perspective. The leadership quarterly, 6(2), 219-247. https://doi.org/10.1016/1048-9843(95)90036-5

Grobler, A. \& Horne, A. L. (2017). Conceptualisation of an ethical risk assessment for higher education institutions. South African Journal of Higher Education, 31(2), 154-171. https://doi.org/10.20853/31-2-1032

Gumede, D. C. (2014). The challenges of working \& studying at a satellite campus: a case study of the Riverside Campus of the Durban University of Technology. DOCTOR OF TECHNOLOGY IN BUSINESS ADMINISTRATION, DURBAN UNIVERSITY OF TECHNOLOGY. Available: https://openscholar.dut.ac.za/bitstream/10321/1074/1/ GUMEDE_2014.pdf.

Hansen, A., Byrne, Z. \& Kiersch, C. (2014). How interpersonal leadership relates to employee engagement. Journal of Managerial Psychology, 29(8), 953-972. https://doi.org/10.1108/JMP-11-2012-0343

Helmrich, B. (2016). 33 Ways to Define Leadership. Available: http://www.businessnewsdaily.com/3647 (Accessed 13 December 2016).

Heres, L. \& Lasthuizen, K. (2013). From ethical competence to ethical leadership. Achieving Ethical Competence for Public Service Leadership, 51.

Hirtle, C. (2016). Employee engagement for Workplace success. Available: www.csmls.org.

Jewe, R. D. (2008). Do business ethics course work? The effectiveness of business ethics education: An empirical study. Journal of Global Business Issues, Conference Edition, 2, 1-6.

Kalshoven, K. \& Boon, C.T. (2012). Ethical Leadership, Employee Well-Being, \& Helping. Journal of Personnel Psychology, 11(1), 60-68. https://doi.org/10.1027/1866-5888/a000056

Kalshoven, K. \& Den Hartog, D.N. (2009). Ethical leader behavior \& leader effectiveness: The role of prototypicality \& trust. International Journal of Leadership Studies, 5(2), 102-120.

Kuo, Y.K. (2013). Organizational commitment in an intense competition environment. Industrial Management \& Data Systems, 113(1), 39-56. https://doi.org/10.1108/02635571311289656.

Kretzschmar, L. \& Bentley, W. (2013). Applied Ethics \& tertiary education in South Africa: Teaching Business Ethics at the University of South Africa. Verbum et Ecclesia, 34(1). https://doi.org/10.4102/ve.v34i1.804

Kulati, T. \& Moja, T. (2001). Leadership. In: The challenges of change in Higher education organisation. 156.

Lin, L.-F. \& Tseng, Ch-Ch. (2013). The influence of leadership behavior \& psychological empowerment on job satisfaction. The International Journal of Organizational Innovation, 5(4), 21-29.

Mabelebele, J. (2013). Why Governance, Leadership \& Management in Higher Education matter? In: Proceedings of HELM LEAD workshop Gauteng, 15 October 2013. HESA,2018.

MacGregor, K. (2015). Thoughts \& Experiences of African University Leaders Durban: University World News. Available: www.universityworldnews.com. (Accessed 10 August 2017).

MacGregor, K. (2012). Transforming a former bastion of apartheid. UWN - The global window on Higher Education. Copyright 2020 University World News. South Africa. 13 May 2012. Available: https://www.universityworldnews.com/post.php?story=20120505182321320 
Mardanov, I. T., Heischmidt, K. \& Henson, A. (2008). Leader-member exchange \& job satisfaction bond \& predicted employee turnover. Journal of Leadership \& Organizational Studies, 15(2), 159-175. https://doi.org/10.1177/1548051808320985

Mayer, D. M., Kuenzi, M., Greenbaum, R., Bardes, M. \& Salvador, R. (2009). How low does ethical leadership flow? Test of a trickle-down model. Organizational Behavior \& Human Decision Processes, 108(1), 1-13. https://doi.org/10.1016/j.obhdp.2008.04.002

Mendes, F. \& St\&er, M. W. (2011). Positive organisation: The role of leader behaviour in work engagement \& retention. SA Journal of Industrial Psychology, 37(1), 1-13. https://doi.org/10.4102/sajip.v37i1.900

Mukherjee, A. \& Malhotra, N. (2014). Does role clarity explain employee-perceived service quality? A study of antecedents \& consequences in call centres. International Journal of Service Industry Management, 17(5), 444-473. https://doi.org/10.1108/09564230610689777

Ngcamu, B.S. and Teferra, D., 2015. How well do university staff understand transformation? A case of a merged South African University. International Journal of Educational Sciences, 8(2), 305-312. https://doi.org/10.1080/09751122.2015.11890252

Ngcamu, B. S. \& Teferra, D. (2015b). Leadership \& transformation in a South African university.

Oates, V. (2013). Instilling Ethical Leadership in Business. Available: http://www.gaaaccounting.com/instilling-ethical-leadership-in-business. (Accessed 29 November 2016).

Obiwuru, T. C., Okwu, A. T., Akpa, V. O. \& Nwankwere, I. A. (2011). Effects of leadership style on organizational performance: A survey of selected small scale enterprises in Ikosi-Ketu council development area of Lagos State, Nigeria. Australian Journal of Business \& Management Research, 1(7),100.

Ofori, G. (2009). Ethical leadership: Examining the relationships with full range leadership model, employee outcomes, \& organizational culture. Journal of Business Ethics, 90(4), 533-547. https://doi.org/10.1007/s10551-009-0059-3

Quintal, G. (2012). Public protector: What we need are ethical leaders. Available: http://mg.co.za/article (Accessed 11 April 2016).

Sankar, Y. (2003). Character not charisma is the critical measure of leadership excellence. Journal of Leadership \& Organizational Studies, 9(4), 45-55. https://doi.org/10.1177/107179190300900404

Schaufeli, W. \& Bakker, A. (2001). Work \& well-being: towards a positive approach in occupational health psychology. Gedrag \& Organisatie, 14, 229-253.

Schulze, S. (2006). Factors influencing the job satisfaction of academics in higher education. South African Journal of Higher Education, 20(2), 318-335. https://doi.org/10.4314/sajhe.v20i2.25576

Sekaran, U. \& Bougie, R. (2016). Research methods for business: A skill building approach. 4th Edition ed. New York: John Wiley \& Sons.

Sethuraman, K. \& Jayshree, S. (2014). Effective leadership styles. International Business Research, 7(9), 165-172. Available: http://search.proquest.com/docview (Accessed 18 June 2015). https://doi.org/10.5539/ibr.v7n9p165

Shaw, J. \& Newton, J. (2014). Teacher retention \& satisfaction with a servant leader as principal. Education, 135(1), 101-106.

Shokane, M., Stanz, K. \& Slabbert, J. (2004). Description of leadership in South Africa: Organisational context perspective. SA Journal of Human Resource Management, 2(3), 1-6. https://doi.org/10.4102/sajhrm.v2i3.46

Sims, R. R. \& Brinkman, J. (2002). Leaders as moral role models: The case of John Gutfreund at Salomon Brothers. Journal of Business Ethics, 35(4), 327-339. https://doi.org/10.1023/A:1013826126058

Sindane, A. (2011). Values \& ethics enter the real world: a framework for public leadership \& governance. Koers, 76(4), 751-769. https://doi.org/10.4102/koers.v76i4.419

Sivan\&a, S.S. (2007). Hindu Ethics 2007. Durban, Kwa-Zulu Natal: Divine life society.

Swanson, R. (Nov.-Dec., 1974). The teacher as a leader. College Student Journal, 8, 40-45.

Taylor, J. \& Machado, M. D. L. (2006). Higher education leadership \& management: From conflict to interdependence through strategic planning. Tertiary Education \& Management, 12(2), 137-160. https://doi.org/10.1080/13583883.2006.9967164 
Technology, D. U. O. (2016). Durban University of Technology - Annual report. Durban: DUT. Available: http://www.dut.ac.za/wp-content/uploads/2012/06/DUT_AR2016_web.pdf (Accessed 23 October 2018).

Trevino, L.K., Hartman, L.P. \& Brown, M. (2000). Moral person \& moral manager: How executives develop a reputation for ethical leadership. California Management Review, 42(4), 128-142. https://doi.org/10.2307/41166057

Treviño, L.K., Brown, M. \& Hartman, L.P. (2003). A qualitative investigation of perceived executive ethical leadership: Perceptions from inside \& outside the executive suite. Human Relations, 56(1), 5-37. https://doi.org/10.1177/0018726703056001448

Van Ameijde, J.D., Nelson, P.C., Billsberry, J. \& Van Meurs, N. (2009). Improving leadership in higher education institutions: A distributed perspective. Paper presented at the Higher Education. December 2009. 763. Available: https://doi.org/10.1007/s10734-009-9224-y

Van Niekerk, M. M. (2005). Transformational leadership at a higher education institution. Master of Arts, UNISA.

Van Niekerk, W. M., De Klerk, M. \& Pires-Putter, J. K. (2017). Conflict management styles \& work-related well-being among higher education employees. Journal of Psychology in Africa, 27(3), 221-226. https://doi.org/10.1080/14330237.2017.1321841

Van Schalkwyk, F., Willmers, M. \& Czerniewicz, L. (2004). Open data in the governance of SAHE. 55. Available: http://www.opendataresearch.org/sites/default/files/publications/Open\%20Data\%20in\%20the\%20Governance\% 20of\%20South\%20African\%20Higher\%20Education\%20WEB.PDF. (Accessed on 12 July 2017).

Van Zyl, E., Dalgish, C., du Plessis, M., Lues, L., Pietersen, E., Ngunjiri, F. \& Kablan, P. (2016). Leadership in the African Context. 2nd edn. Cape Town: Juta \& Co (Pty) Ltd.

Van Zyl, E. (2014). The role of self-leadership in becoming an ethical leader in the South African work context. African Journal of Business Ethics, 8(2). https://doi.org/10.15249/8-2-82

Van Zyl, E. \& Lazenby, K. (1999). Ethical behaviour in the South African organizational context: Essential \& workable. Journal of Business Ethics, 21(1), 15-22. https://doi.org/10.1023/A:1006095930895

Walumbwa, F.O. \& Schaubroeck, J. (2009). Leader personality traits \& employee voice behavior: mediating roles of ethical leadership \& work group psychological safety. Journal of Applied Psychology, 94(5), 1275-7286.

Wiza, M. \& Hlanganipai, N. (2014). The Impact of Leadership Styles on Employee Organisational Commitment in Higher Learning Institutions. Mediterranean Journal of Social Sciences, 5(4), 135-141. https://doi.org/10.5901/mjss.2014.v5n4p135

Yang, Y.-F. (2014). Studies of transformational leadership: evaluating two alternative models of trust \& satisfaction. Higher Education Quarterly, 67(3), 275-294. https://doi.org/10.2466/01.04.PR0.114k27w2PMid:25074300

Zuma, J. (2000). The need to restore the moral fibre of our nation. In: Proceedings of seminar: The moral renaissance-government, politics, ethics \& spirituality. Johannesburg, 3-4 May 2000. 3-4. 